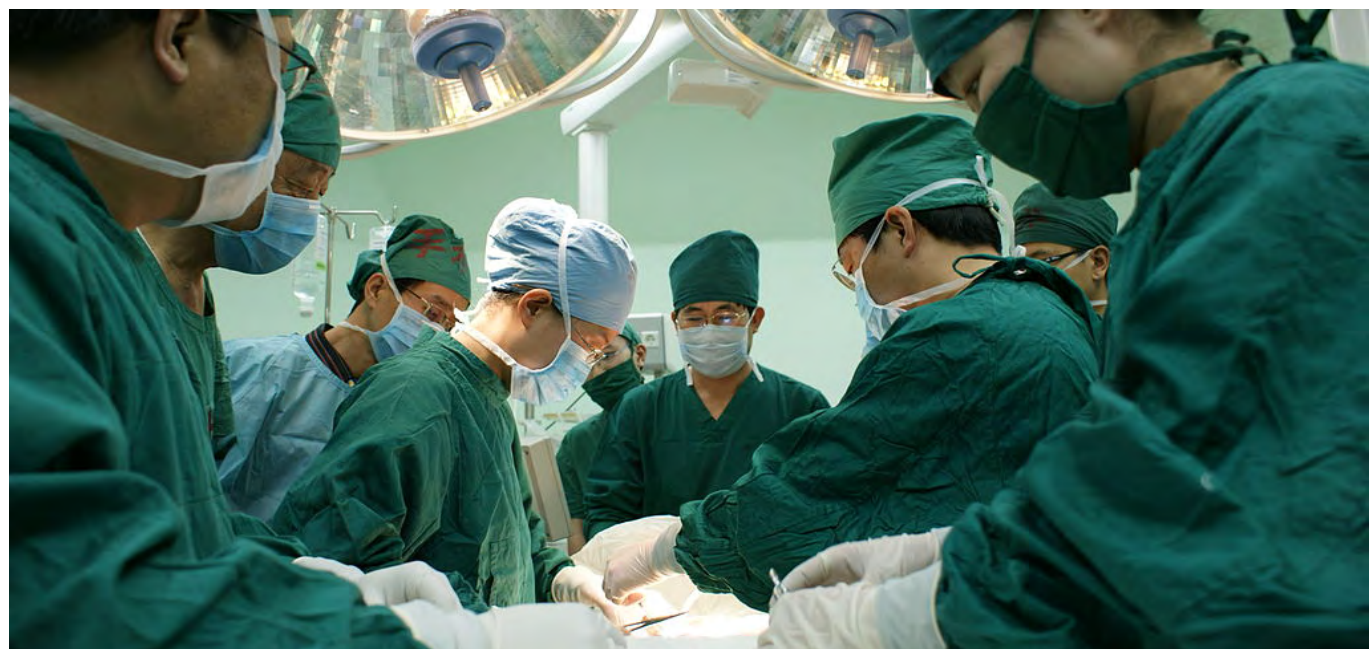

\title{
Shared Visions: The Gift of The Eye
}

Organ transplant. PC: CMSRC.

Sylvia J. MARTIN

Organ transplantation as discussed in the occult economies literature is associated with illicit activities and uncanny circumstances, and is fuelled by socioeconomic disparity. Discussing corneal transplantation as depicted in the Hong Kong-Thai film The Eye, this essay reflects on the symbolic and affective aspects of gifting the organ that helps us to mediate the world and which is associated with personal identity. It argues that through the genre of horror, cultural meanings of corneal transplantation are heightened that include the notion of tethering individuals through premonitory visions. In its portrayal of corneal donation and reciprocity, The Eye offers a warning about predictive knowledge.
W alking around Hong Kong during the seventh month of the lunar calendar, in the weeks leading up to the annual Hungry Ghost Festival, or Yue Laan Jit (孟兰节), it is not unusual to come upon local residents casually engaging with the supernatural. With little fanfare, and as pedestrians rush past, individuals burn incense, paper money (referred to as 'hell money', 陰司 紙), candles, and other items in a tin bucket on the sidewalk or edge of the street, often with prepared foods and fruits, in a TaoistBuddhist ritual of appeasing lingering spirits after the Gates of Hell open. Operas are staged in various neighbourhoods not just for living audiences, but for spectral ones as well in an effort to pacify and entertain the ghosts who wander the city. According to popular Chinese religion, 'hungry ghosts' (餓鬼) are unsettled spirits of people who met unfortunate deaths, and the festival is devoted to feeding and placating these roaming ghosts (Constable 1994, 111; Guang 2011). Burning incense and 
paper money for Yue Laan Jit does not preclude a person's affiliation with, or participation in, other religions. A designated time once a year in which the worlds of the living and unliving are set to collide is not unlike Western Europe's All Hallows' Eve, or its predecessor Samhain (Santino 1983, 5).

Yet, making preparations for expected visitors from the supernatural world at ritualised times is one thing; being confronted with unsolicited shadows and spirits from that world in daily life is another. While conducting research on the production processes of the Hong Kong film industry, I found that throughout the year actors claimed to occasionally see ghosts, or were rumoured to be possessed by them while they were working. These supernatural encounters were more common if they were filming late at night in remote areas, and even more so when filming ghost movies or films with violent scenes (Martin 2017). Ghosts were understood to be mischievous and attracted to performance activity and enactments of danger, especially by actors and stunt workers who hailed from Cantonese opera troupe traditions. Production management would often offer lai see (利是, or 'red packets') as a token of appreciation to performers for engaging in dangerous activity. Starting the day's filming by burning incense to appease any lingering ghosts and consulting with astrologists for an auspicious filming schedule were other practices that linked the occult and the film industry.

But, taking it one step further, what if seeing ghosts in the ordinary landscape of the city while going about one's business during the daytime was a common occurrence, for instance when standing at a traffic light on a busy street, or while eating at a noodle shop? Or what if one saw images that foretold imminent death? The 2002 Hong Kong-Thai film The Eye (Gin Gwai) explores those very experiences through its telling of a story about corneal transplantation. I argue that through the genre of horror, cultural meanings of vision are highlighted and heightened that go beyond the political economic analysis of extraction

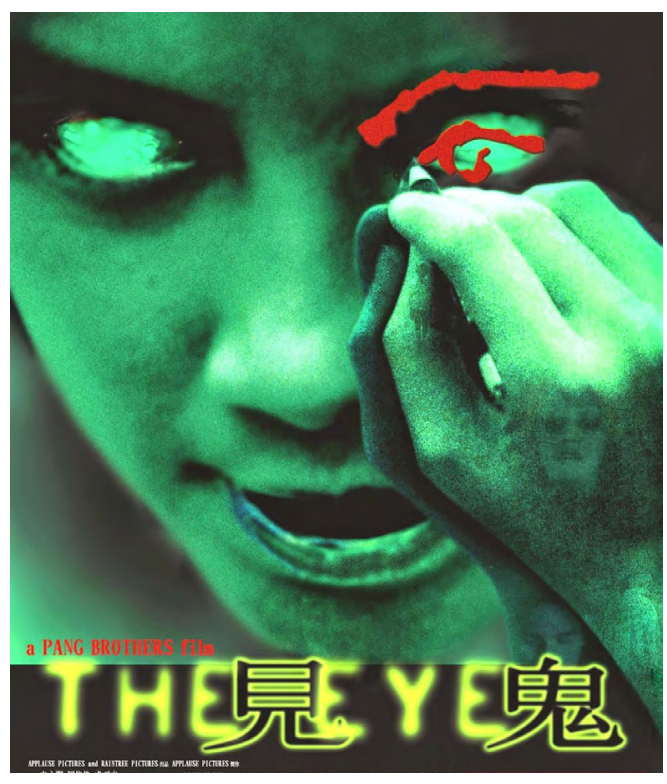

The Eye (Gin Gwai), 2002.

and exchange. In my discussion of corneal transplantation in The Eye, I account for the symbolic and affective aspects of acquiring such an evocative body part.

In the film, a young Hong Kong woman, Mun, who has been blind for most of her life, receives a double cornea transplant. Soon after her operation, she is confronted with disturbing visions: ghosts, and dark, shadowy figures that surround people who will die shortly after. Mun's family becomes concerned over her behaviour as she becomes agitated and withdrawn, and as they see her talk to herself, they start to suspect that Mun is possessed. It becomes increasingly apparent that what Mun referred to in the opening scene as 'fresh eyes' are no ordinary corneas, thus raising doubts about their origins. At the encouragement of a Daoist priest, and accompanied by her psychotherapist, Mun travels to Thailand to seek out more information about the source of the corneas.

The ability to see ghosts or signs of impending doom is not celebrated or commodified in The Eye; rather, through 
the plot device of transplantation, the film depicts the burden of foresight, the lonely responsibility of premonition. In a time when predictive technologies are increasingly valued despite their biases-not just in the health sector, but also in politics, policing, finance, job performance, and educational achievementand individuals revise and refine their actions accordingly, The Eye resists the endeavour of all-seeing, all-knowing capability.

\section{The Occult Economies of Transplantation}

With globalisation having primed the conditions for the dis- and re-embedding of organs from the Global South to the Global North, from East to West, a prominent issue in the social science literature on organ transplantation is trafficking (see Cohen 2003; Comaroff and Comaroff 1999, 2000; ScheperHughes 2000, 2007, 2009). In their exploration of occult economies, Jean and John Comaroff (1999, 280-81) offer the case from South Africa of a man arrested for attempting to sell a pair of eyes in a shopping mall as an example of a neoliberal environment in which 'scams and stratagems ... flow from a promiscuous mix of scarcity and deregulation'. 'This traffic,' Scheper-Hughes $(2009,8)$ explains, 'is fueled by a neo-liberal economy that values humans as commodities and the "self" as a market mechanism-suppliers, brokers, buyers, sellers, and processors-of re-usable body parts, pushing human agency and hyperindividualism to their extreme limits.' ScheperHughes (2000) focussed on the circulation of kidneys, which are considered more desirable if sourced from living donors/sellers, in many cases extracted under dubious terms from vulnerable, debt-ridden people whose consent is underinformed and whose access to healthcare is limited. The plundering of such 'medical material' is especially prevalent in India, South America, and South Africa (Scheper-Hughes 2009, 13). Correspondingly, the film plays up the fear of circulating corneas as a possibly ill-gotten gain, mirroring what Comaroff and Comaroff $(2000,317)$ describe of occult economies as 'the use of the bodies of some for the empowerment of others'.

In fact, organ trafficking has thrived in the face of widespread socioeconomic upheaval and insecurity stemming from privatisation, with even national governments implicated in such schemes (Comaroff and Comaroff 1999, 291). Occult economies are premised upon an uneasy convergence of 'magical technologies and mysterious modes of accumulation' (Comaroff and Comaroff 1999, 284), and the Comaroffs $(2000,316)$ point to ScheperHughes's research on organ trafficking in Latin America and elsewhere as part of a broader phenomenon in which the commodification of body parts relies upon 'forms of power/ knowledge that transgress the conventional, the rational, the moral'. Illicit and occult activities thus intersect amid growing socioeconomic inequality. Scheper-Hughes's (2007) work on organ transplantation also contributes to a valuable literature on the ethical and social dimensions of defying disease and death through the circulation of kidneys not just across the globe but also within families, revealing cases of kidneys given under the 'tyranny' of pressured family relationships-particularly 'sacrificial' female kin-and, likewise, the weight of receiving such an outsized gift.

Yet, corneal transplantation brings its own, mediating complications, as corneas help enable vision, and vision is one of the five senses used to perceive the world(s) around us; studies and social commentary attest to crosscultural ideas that sight is for many the primary and privileged sense (Enoch et al. 2019; Aldama 2017). While the kidneys that Scheper-Hughes focuses upon provide what donor organisations refer to as the 'gift of life', imperative as they are for the maintenance of bodily health they nevertheless serve internal needs; corneas, however, are external features that help sustain sight (and in the case of the film, also 'the gift of second sight', or clairvoyance), and literally 


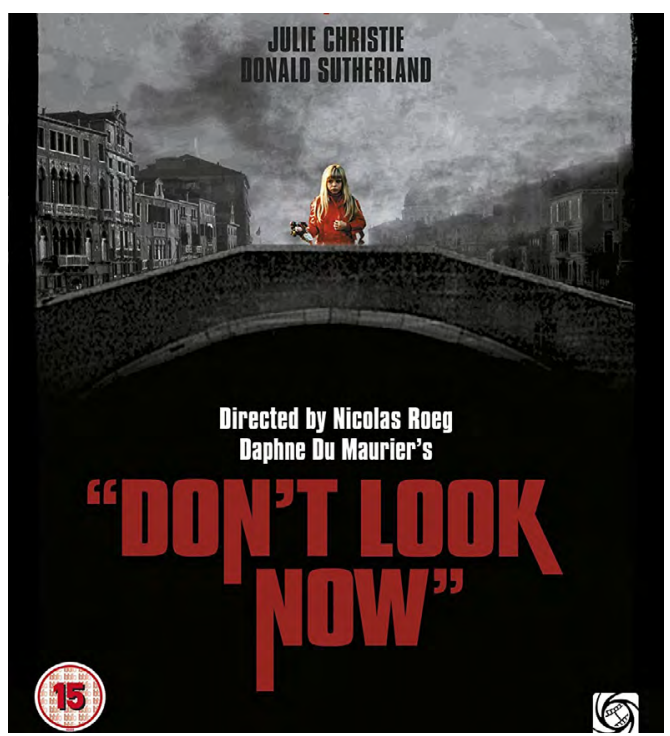

shape one's outlook on the world(s)-occult and ordinary. Eyes are also associated with personal identity, as a study on donor relatives illustrates (Sque and Payne 1996), as well as with identification and surveillance, which makes corneal transference from one person to another more provocative than with most internal organs. Corneal transplants also imply notions of 'shared vision'. The film plays upon the uncanniness of receiving someone else's eyes-of tethering individuals through frightful visions. Finally, I suggest that in its depiction of cornea donation and an act of reciprocity, we can take from The Eye a warning about predictive knowledge.

\section{'The Thing Given Is Not Inactive'}

Supernatural films such as the UK/Italy movie Don't Look Now (1973) and Hong Kong's My Left Eye Sees Ghosts (2002) have utilised the association of eyes with second sight, with visions of the occult; The Eye spawned

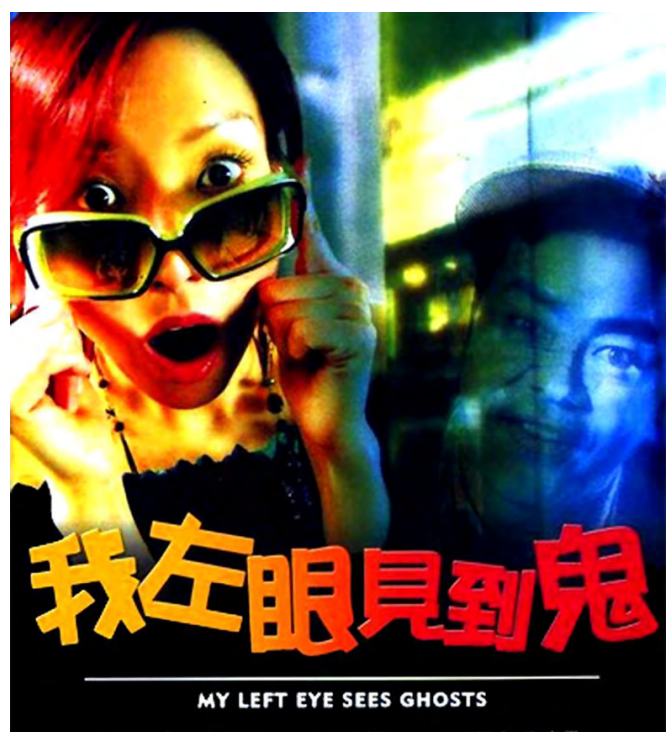

Don't Look Now (1973) and My Left Eye Sees Ghosts (2002).

numerous sequels and a Hollywood remake. The beginning of The Eye seems far from the world of underground organ transplants, and we learn that Mun has led a seemingly full life prior to her transplant-she moves about the city with apparent ease, she enjoys performing violin with an orchestra for the blind, and she lives with her sister and her grandmother, with whom she seems close. After her transplant in a calm, sterile Hong Kong hospital environment (the source of her corneas not yet revealed), Mun is assigned a psychotherapist, Doctor Wah, to help her adjust to seeing and acquire what he refers to as a 'visual vocabulary'she must learn to identify objects on sight, as opposed to touching them first. Yet Mun's postoperative world shifts in other, uneasy ways: she starts to sense that the paranormal and premonitions she sees are not seen by others, while at the same time, she is dismissed from her reassuringly familiar orchestra community because she is no longer blind-a loss that she had not anticipated.

According to a study on adolescent corneal transplantation, recipients can experience depression, anxiety, despair, and fear as well as 
feelings of guilt towards the organ donor, and it is likely that adults share some of these same reactions (Tong et al. 2009). Authors of a study on the impact of corneal transplantation on adults in Iran note of recipients, 'the fact that they have part of another person's body, does not escape them, leading to complex moral and psychological problems for the patients. The multiplicity of potential factors affecting the individual psyche is that such an experience can be beyond individual tolerance' (Amiri et al. 2017, 4056). There may be, after all, a quality of unnaturalness (or, supernaturalness) in lifting 'medical material' from a corpse and transferring it into a live being, activating it into use, which the film exploits. In Magical Interpretations, Material Realities, Henrietta L. Moore and Todd Sanders (2002, 1-2) note that science and the occult have long been entwined, such as the popularity of nineteenthcentury spiritualism alongside the advances of Victorian science, and contemporary social scientific literature notes the ontological complexity of what it means to look out at the world with eyes other than one's own. In a British psychological study on donor relatives, some family members interviewed said that they could not go through with the deceased's wish to donate their eyes, the reasons including that the deceased 'would need them in an afterlife'. Indeed, the authors further note that '[a]ttached to the precise feelings about the eyes are contemporary images in horror films of empty eye sockets' (Sque and Payne 1996, 1364).

While she focussed on kidneys, not corneas, Scheper-Hughes draws from the work of French sociologist and anthropologist Marcel Mauss to invoke the spiritual aspect of organ donation. She employs Mauss's notion of gift exchange to underscore the 'tyranny' of receiving such an indebting gift from a family member, and also the pressure on family members (especially females) to sacrifice an important organ for the benefit of another person (see also Fox and Swazey 1978). More importantly in the case of The Eye, Scheper-Hughes adapts Mauss's $(1990,11)$ emphasis on the Maori concept of hau ('spiritual power') to describe the spiritual dimension of gift exchange. The gift, Mauss explains, impels its recipient to reciprocate. In Maori law, Mauss (1990, 12 with italics added) identifies that obligation as stemming from

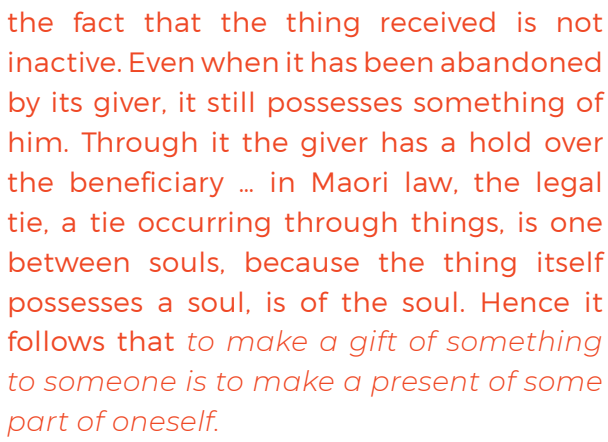

In Mauss's application of Maori law, Mun's corneas therefore contain some essence of her donor, who was a young woman named Ling who committed suicide. Mun realises that when she looks in the mirror she in fact sees a different woman than who others see-Ling, it turns out. Mun and Ling are inextricably linked, and Mun comes to realise through the advice of a Daoist priest that in order to free herself from these disturbing visions of ghosts and warnings of death, she must not only thank Ling, but reciprocate in some way.

\section{Shared Vision}

In leading up to the act of reciprocity, Mun begs Doctor Wah to help her address the frightening visions, and starts to keep her bedroom lights off and immerse herself in darkness. Her grandmother and sister seek assistance of a more spiritual nature, first burning money outside their building at night, and later inviting the Daoist priest to perform an exorcism in Mun's bedroom. Earlier in the film, the priest conferred with Mun's neighbours, whose son had committed suicide, his ghost repeatedly appearing to Mun after her transplant. After Mun's therapist convinces 
her eye surgeon to divulge information about Mun's donor, he and Mun travel to Thailand, where the donor, Ling, lived.

Thailand provides cheap resources and labour for Hong Kong (see also Knee 2009). Besides the country's beaches offering a budget vacation destination, Thai women contribute a steady supply of labour for Hong Kong's foreign domestic worker scheme in unstable and sometimes abusive conditions that help animate Hong Kong's prosperity. Mun and Doctor Wah find out that Ling was a Thai-born Chinese who even as a child was harassed and shunned by the local villagers for her ability to foresee death. 'From time to time, she would weep outside someone's door. Afterwards, a person in that house would pass away, a childhood acquaintance tells them. Eventually, as a young woman, Ling foresaw a fire that would kill 300 people. Flashback footage shows Ling's distress in trying to frantically warn villagers of her vision. They scorn her, and in the aftermath of the disaster, Ling, who apparently is tormented by her foreknowledge and her inability to change the future, hangs herself.

The movie does not clarify if it had been Ling's wish to donate her corneas, or if her surviving mother decided for her. Nevertheless, voiceover from the Daoist priest iterates Mun's obligation to Ling: 'We believe that the very last consciousness of a person just before they die becomes the consciousness of the ghost ... The woman whom Ms. Wong [Mun] keeps seeing after resuming her sight, we have to resolve her problems so that she can move on.' Mun meets Ling's mother, who is embittered over Ling's suicide, resentful that her daughter 'gave up' on herself. Mun asks to spend the night in Ling's bedroom after their long journey, and in Ling's bed, Mun says aloud: 'I know you've wanted me to come here all this time. Well, here I am now. What do you want to tell me?'

At 3am, Mun hears Ling calling her mother for help, and realises that the dead girl wants that she bring her mother to her. Mun then begs Ling's mother to come up to Ling's room where she hanged herself, telling the mother:
'Since she killed herself, she's been trapped in a time warp ... constantly repeating her suicide.' The mother refuses to cooperate, insisting that she cannot forgive Ling for giving up on herself. Mun runs back to Ling's room, and finally the mother, hearing Ling's voice calling for her help, runs to Ling's room. There, Ling appears alive, lying on the floor, cut down from the sheet with which she hanged herself. Sobbing, Ling apologises to her mother, who in turn lovingly offers her the forgiveness that her daughter desperately sought. They clasp hands, and Ling's face, finally at peace, morphs into Mun's. It is now Mun lying on the floor, Ling nowhere in sight. Mun did what the priest suggested: resolve Ling's problem so that she could move on. Mun merged her entire body with Ling's, sharing the same form, to stage this final farewell with the mother. She thus, symbolically at least, reciprocated Ling's gift.

The film seemingly concludes with this act of reciprocity. Yet while stuck in traffic on her way to the airport, Mun discovers to her horror that shadows swarm the street around her, and she realises death must be impending. Panicked, she runs through traffic to try to warn everyone around her to run, but no one believes her. Intercut with this footage are flashback images of Ling running through her village begging everyone to leave because she foresaw a deadly disaster, highlighting their twin experiences of foresight to no avail. In Mun's time, a mass explosion occurs, killing dozens of the people she tried to warn. She is saved by Doctor Wah, but not before shards of glass fly into her corneas, blinding her.

The film finally ends with Mun looking calm amid the busy ferry pier of Hong Kong, meeting Doctor Wah, who now is her love interest, with her serene voiceover that Ling has left her. She states that she holds no resentment towards Ling: 'Since I saw and experienced the same pain that she did.' Evidently, even after Mun and Ling's exchange, those corneas remained enchanted. Mun, in a less drastic manner than Ling, was relieved of the burden of premonitions and predictions, and the tormented aftermath of helplessness. The two 
women shared not only ocular tissue, but also a vision of haunted beings and forewarnings of death. Foresight in particular can be isolating and as Ling's story showed, alienating. Yet, in Mun's act of reciprocity, she essentially embodied Ling, fusing them even more fully, a conscious act of recipient/donor solidarity.

\section{Eyeing Empathy}

Receiving a cornea transplant differs from transplantation of unseen internal organs especially given the various meanings and functions associated with the eye. Eyes signify a person's identity and authenticity; they also ostensibly enable vision, and vision is what conveys so much of the world to us. The eyes thus bring the world in to the observer and at the same time, communicate something outwards of the observer. A kidney, while so imperative to our body's functioning, does not mediate between us and the world(s). The Eye offers an East and Southeast Asian imaginary of transplantation and gifting-appropriately enough, its writers include a set of Hong KongThai twin brothers-that may be dismissed as technophobic, although it is also a positive portrayal of someone living with a sensory impairment (e.g. a loving family, a social life, a budding romance). But the film illustrates the empathy that an organ recipient can feel for their donor; in this case, quite literally seeing the world through their eyes, binding them together.

While strands of popular culture urge people to identify and nurture their individual 'superpower', Mun's reluctance to be 'an extraordinary person', as she terms it, is refreshing. 'I don't want to be terrified every night,' she told her therapist. Refusing visions of the future, which suggests a critique of predictive knowledge, may actually leave room for new potentialities. As Faye Ginsburg and Rayna Rapp (2020, S7) note in their work on disability: "Beyond "victimology" lies disability's world-making creativity.' 
This text is taken from Made in China Journal: Volume 5, Issue 2, 2020 , edited by Ivan Franceschini and Nicholas Loubere, published 2020 by ANU Press, The Australian National University, Canberra, Australia.

doi.org/10.22459/MIC.05.02.2020.14 